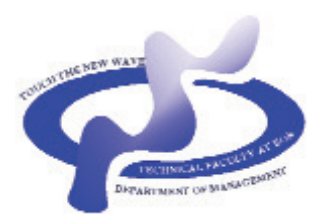

www.sjm06.com
Serbian

Journal

of

Management

\title{
THE CRITICAL FACTORS OF IT GOVERNANCE AND ITS IMPACT ON ORGANIZATIONAL PERFORMANCE IN MALAYSIAN MANUFACTURING INDUSTRY
}

\author{
Bentolhoda Abdollahbeigi* and Farhang Salehi \\ Multimedia University Jalan Multimedia, Faculty of Management, \\ 63000, Cyberjaya, Malaysia
}

(Received 01 October 2018; accepted 19 February 2019)

\begin{abstract}
The purpose of this study is to examine the extent to which senior management's involvement and demographics of organizational affect the effectiveness of IT governance with the performance of organizations. This is a combination of exploratory and descriptive research that aims to investigate the determinants of IT governance and its effects on organizational performance in Malaysian manufacturing companies. The sample size of 357 collected for this research. Structural equation modeling (SEM) was utilized in this research to investigate the measurement and structural model simultaneously. The findings demonstrated the relationships between the senior management's involvement and organizational demographics, effective its governance and organizational performance in manufacturing companies in Malaysia. This research is the construction of a theoretically based model which assimilates the senior management's involvement and organizational demographics, effective IT governance, and performance of organizations. Likewise, discover the most crucial elements that affect effective IT governance to improve the manufacturing company's performance.
\end{abstract}

Keywords: IT governance in Malaysia, involvement of senior management in IT, organizational demographics, effective IT governance, performance of organization

\section{INTRODUCTION}

The notion of governing IT possessions has become an extremely common and prominent ideal within many organizations in the last decade. Curiosity in It all governance provides been powered by an elevated concentrate on risk aversion and mitigation, economic accountability and control, in addition to a desire to make sure

* Corresponding author: hoda_beigi@yahoo.com

DOI: $10.5937 /$ sjm15-19019 
prudent and value-based expenditure in IT (IT) assets (Rubino \& Vitolla, 2014). Because of the high investment manufactured in IT as well as the critical results IT is wearing the achievement of the business, a large number of resources are accustomed to acquire and take care of IT with reasonable distribution across a business. ITG is an element of the decisionmaking framework, including processes, in addition to relational tools to control and control. Research commonly acknowledges it as an art of business with high significance in aligning and attaining organizational value using IT (Teo et al., 2013). However, the development of IT governance remains a challenge to organizations. Recently, creating and implementation of effective IT governance has been highly considered by modern businesses. Effective IT governance guarantees the alignment between business goals and IT. In order to accomplish the firm's overall performance goals, it is essential for businesses to have effective IT governance (Vaswani, 2003). To do so, some IT governance strategies should be utilized that promotes behaviors based on the firm's strategy, objective, norms, lifestyle, and values (Ali \& Green, 2012). On the other hand, businesses without effective IT all governance are affected from inaccuracy of information quality, inefficiency of working costs, incorrect estimation of IT tasks' costs (under specification and more than budget), failure in competitiveness, inefficient overall performance of IT divisions or the whole organization; these problems will reduce the overall performance of the business (De Haes et al., 2013). Research demonstrates businesses with better ITG boost their income levels by $25 \%$ compared to organizations with poor governance with the same objectives. The IT Governance
Institute is present to assist business leaders in understanding the need for IT objectives to align with business goals, the way in which it includes value, and the way in which performance is measured, the resources distributed accordingly, and its risk mitigation ability (Othman, 2016). The various characteristics of particular types of businesses and market sectors were not considered in their contribution to show the efficacy of ITG in firms (Ali \& Green, 2012). It should be observed that the elements resulting in the efficacy of an ITG can't be generalized to each company and sector differs using its characteristics. As a result, it is necessary for organizations to create an effective ITG to be able to achieve a far more effective IT use. To be able to execute an effective ITG, a place mechanisms linked to ITG is necessary like a steering committee for this, an organizational framework for this, etc.

\section{IT GOVERNANCE IN MALAYSIA}

Information technology governance (ITG) is a new field of study in Malaysia with rather scarce research carried out in this area in the Malaysian context. The IT infrastructure in organizations is becoming more complicated as businesses grow regarding yearly revenue and employee intake. IT has a significant effect on how businesses are run by organizations. In order to emphasize its importance, it is noted that even during economic decline, significant investments are continuously made in IT (Callahan\& Keyes, 2004). Organizations depend on IT due to the requirement for better management, controls, and governance of the investments in IT. As such, IT Governance (ITG) has a prominent 
role in making sure that the investments are able to provide value and minimize risks. ITG describes the framework for accountability as well decision rights to motivate the behaviors the desirable behavior in the use of IT (Veerankutty \& Ali, 2016). Studies reveal that firms with a sound ITG in place are able to increase their returns on assets by $20 \%$ compared to firms with a lack of governance. Moreover, having a sound ITG leads to having an enhanced IT result (Gartner, 2010).

\subsection{Involvement of Senior Management in IT}

Senior management involvement is an essential indicator of effective IT governance, IT and business alignment. Senior management involvement can occur normally, or by the explicit appointment of a project, champion takes from the senior management. The positive impact of senior management involvement on effective IS planning determined the correlation between senior management support and organizational activity achievement, in addition, has been completely researched (Bouwes, 2013). A significant positive correlation between senior management involvement and IT governance provides been discovered by (Ali \& Green, 2012). The need for senior management involvement, in addition, has mentioned by (Weill \& Ross, 2004) who discovered a significant positive correlation with the involvement of senior management and the performance of IT governance score. The complete set of recommended processes is allowed by the involvement of senior management (Castro \& Carvalho, 2012). A lack of senior management involvement, in addition, has been demonstrated to be negatively correlated with IS planning effectiveness (Iden \& Eikebrokk, 2015). Found evidence using both quantitative and qualitative techniques which senior management involvement includes a critical positive relationship with IT governance success. Marnewick and Labuschagne (2011), Recognized senior management involvement the most important enabler of business and IT alignment. In this study has considered the two components of involvement of senior management in IT such as: 1) IT Strategy Committee; The IT strategy committee is focused on establishing effective IT governance by giving enough resources for attaining their objectives linked to IT strategy and IT governance. The IT strategy committee can be accountable for providing the management with direction linked to IT strategy. 2) IT Steering Committee: The steering committee for IT is a lateral organizational coordination in relation to IT. Its management encompasses the workforce from various levels of hierarchy in the organization for a coordinated method of managing the IT resources of the organization. The organization is accountable for establishing an IT Steering Committee, made up of directors and managers from IT and business areas.

\subsection{Organizational Demographics}

The demographics of the companies are marked using the size and age group of the firm. Company size explains the number of staffs and the firm's sales income; however, research results on company size are normally mixed. Research demonstrates there is a contrary relation between firm size and structure-structures of larger companies are not as centralized (Mohamed \& Kaur a/p Gian Singh, 2012). Héroux and Fortin, 
(2017) discovered that firm age is an essential determinant of the options related to implementing a new technology. IT governance, the larger the organization, and thus the more differentiated, the less the pressures to adopt any one particular IT governance activity. This may occur because an organization operates in more than one industry, regulatory or legal environment, or geographic area and it is not likely to be interconnected and have channels that share institutional pressures. Organization age indicates the number of years an organization has been in existence. Research has found age to be a determinant of company profitability (Loderer \& Waelchli, 2010). There are many reasons for the significant association between company age and profitability.

\subsection{Effective IT Governance}

The structures of ITG involve structural or formal mechanisms as well as devices that connect and facilitate horizontal contacts or liaison between the business management and IT functions such as the steering committee. The processes in ITG include the institutionalization and formulation of IT decisions that are strategic or procedures of IT monitoring like the IT balanced scorecard (De Haes et al., 2013). Lastly, the relational mechanisms include the strong participation and cooperation among the executives of the corporate segments and the IT management and business segments (Héroux \& Fortin, 2014). It is crucial to have relational mechanisms in the framework of ITG, and it is essential to achieve and sustain an alignment between your business and IT segments, actually if the best processes and structure already are in place (Guilherme \& João, 2014). ITG qualified prospects for improvement in the performance of IT and this, in turn, leads to improvement in the performance of the company (Nfuka \& Rusu, 2011; Huygh et al., 2018). In this study has considered 3 dimensions of effective IT governance such as: 1) Structure: The structure of ITG includes the mechanisms of functions and responsibilities utilized by a firm to ascertain that the investments in IT can easily achieve the goals of the firm. 2) Processes: Process refers to strategic monitoring and decision making through the use of tools like the IT balanced scorecard. Moreover, it is also referred to as the set of related functions carried out in executing, managing, and monitoring the various activates in IT. 3) Relational Mechanism: Relational mechanisms involve the business participation, and IT segments, strategic dialogues, shared learning, and beneficial communications. It is critical to have relational mechanisms.

\subsection{Organization Performance}

Managers have only utilized financial elements in measuring performance previously; however, it appears that this is insufficient, and this led to the introduction of a tool known as the balanced scorecard that incorporates measures that include financial and non-financial elements in measuring performance since non-financial elements are equally essential financial ones in a measuring system and having both elements in an integrated system will result in superior outcomes for the firm (Kairu et al.,2013). Also, Kairu et al., (2013) regarded the BSC system as one in which the firm evaluates the main measures of performances based on the perspective of performance according to finance, customers, internal business processes, as 
well as learning and growth. The BSC is categorized into four perspectives including finance, customers, internal business processes, as well as learning and growth. This research offers a better understanding of the effectiveness of ITG and its effects on firm performance based on the BSC's four perspectives. Using these understanding, suitable actions could be taken to develop and create an environment that motivates the effectiveness of ITG that improves overall success.

\section{PROBLEM STATEMENT}

Currently, information technology governance has become a critical issue for many companies in various industries; this is even more important for enterprises due to the more complex business processes, more specified tasks and departments. Many companies suffer from extra costs of IT and other processes due to failure in efficient alignment between IT and business strategies which in turn, leads to a low performance of the company.

On the other hand, it is essential to comprehend the techniques to establish and implement an effective ITG. Most studies have analyzed ITG practices and techniques in the private sector (Mohamed \& Kaur a/p Gian Singh, 2012). Even though it has long been acknowledged by public sector firms on the importance of having an effective ITG for the firms to succeed, studies investigating the techniques of establishing an effective ITG in the public sector are scarce. As such, this study aims to determine the factors necessary to establish and implement an effective ITG among organizations in the manufacturing sector. The need to establish and implement an effective ITG is of utmost importance in modern-day business (ISACA,
2012). The significance of the ITG is supported by research, which demonstrates that organizations with better ITG increase their profit levels by $25 \%$ compared to organizations with weak governance with the same objectives. Besides, it was also claimed that having a successful ITG framework is the most significant predictor of generating organizational value from IT. An effective ITG is critical for firms with the aim to reach their corporate objectives. However, the main question in business is finding out which ITG mechanism is the most costeffective and able to generate a higher level of success in ITG in an organization. Also, it is also essential to comprehend the factors that establish the efficacy of ITG, which cannot be generalized to all firms and industry, type as each firm has its characteristics.

There are several researches in the area of IT governance and its relationship with organizational performance; however, there is lack of the examination on IT governance determinants (senior management's involvement and organizational demographics) as well as mediating impact of IT governance effectiveness on organizational performance in an integrated form which will be done in this research (Tan et al., 2011). There are limited researches about IT governance in Malaysia and a seeming lack of awareness studies on IT governance from the Malaysian perspective. Therefore the main research problem for this research is: IT governance importance has been known by organizations, the effect of senior management's involvement and organizational demographics and effective IT governance on organization Performance in Malaysian manufacturing companies is still not well established (Elbanna \& Child, 2007). 


\section{SIGNIFICANCE OF RESEARCH}

The Malaysian government has aimed to boost the nation's manufacturing growth by proposing the Economic Transformation Program (ETP) order to achieve its Vision 2020. In order for organizations to have better performance, they need to have effective ITG. The organizations' ability to have effective ITG is the key factor to boost their performance and ensure their success. Therefore, it is imperative for manufacturing companies to have a better understanding about the factors that influence enhancement of ITG to produce effective ITG and organization Performance. Thus, this research identified the determinant of ITG initiatives and effective ITG in this research would help to achieve organization performance. This study will help clarify for IT managers, practitioners. Establishing a model of IT Governance on effective IT governance and Organizational Performance in the industry of interest will help managers to have a better understanding how Information Technology Governance and effective IT governance fit together in Organizational Performance. The results and findings of the research can have beneficial to supporting Manufacturing organizations in their efforts towards carrying out improvement activities. For managers, the proposed model is intended to provide a long-term strategic guidance as the detailed results will show the specific requirements that can be implemented to enhance organizational capabilities for improved overall performance. This study offers clarification by conceptualizing the relationships among the IT Governance, Effective IT Governance and organization performance.

Therefore Information Technology
Governance is very important in manufacturing sectors. Also, the topic of research has considerable significance in Malaysia. There is limited research about any of its governance in Malaysia and a seeming lack of awareness studies on IT governance from the Malaysian perspective. A significant contribution of the study is the structure of a theoretically structured model which assimilates the senior management's involvement and organizational demographics, effective IT governance and Organizational Performance. This research present, the dimensions of IT Governance on effective IT governance and Organizational Performance provides an all-inclusive knowledge of the study framework and make improvement from the existing knowledge regarding the correlations IT Governance dimensions, effective IT governance and performance of Organizational.

\section{RESEARCH QUESTIONS AND HYPOTHESES}

This study focuses on seven research questions:

RQ1.What's the partnership between involvements of senior management in effective IT governance?

RQ2. What's the result of the involvement of senior management on organizational performance?

RQ3.From what extent effective IT governance mediates the relationship between involvement of senior management and organizational performance?

RQ4.What's the result of organizational demographics on effective IT governance?

RQ5. What's the effect of organizational demographics on organizational performance? 
RQ6.To what extent effective IT governance mediates the relationship between organizational demographics and organizational performance?

RQ7.How does effectively IT governance influence organizational performance?

Therefore, following hypotheses and Conceptual Framework (Figure 1) have been proposed:

H1a: There is a positive significant relationship between Senior Management Involvement and effective IT Governance.

H1b: There is a significant relationship between Senior Management Involvement and Organization Performance.

H1c: Effective IT Governance mediates the partnership between Senior Management Involvement and Organization Performance.

H2a: There is a relationship between Organizational Demographics and Effective IT Governance.

H2b: There is a relationship between Organizational Demographics and Organization Performance.
H2c: Effective IT Governance mediates the relationship between Organizational Demographics and Organization Performance.

H3: There is a relationship between Effective IT Governance and performance of Organization.

Figure 1 shows the conceptual framework of this study.

\section{SAMPLING AND DATA COLLECTION}

The unit of analysis for this research was the Manufacturing organizations. Quantitative method used because of this research to be able to test the hypotheses and also answering questions. The research population contains IT Managers employed by manufacturing companies. Nevertheless, the questionnaire of research emailed to IT managers in manufacturing firms in Malaysia. Samples have got chosen from seven claims of Malaysia because intensely populated and rather several manufacturing industries to be able to let the leads to be generalized to a larger population such as

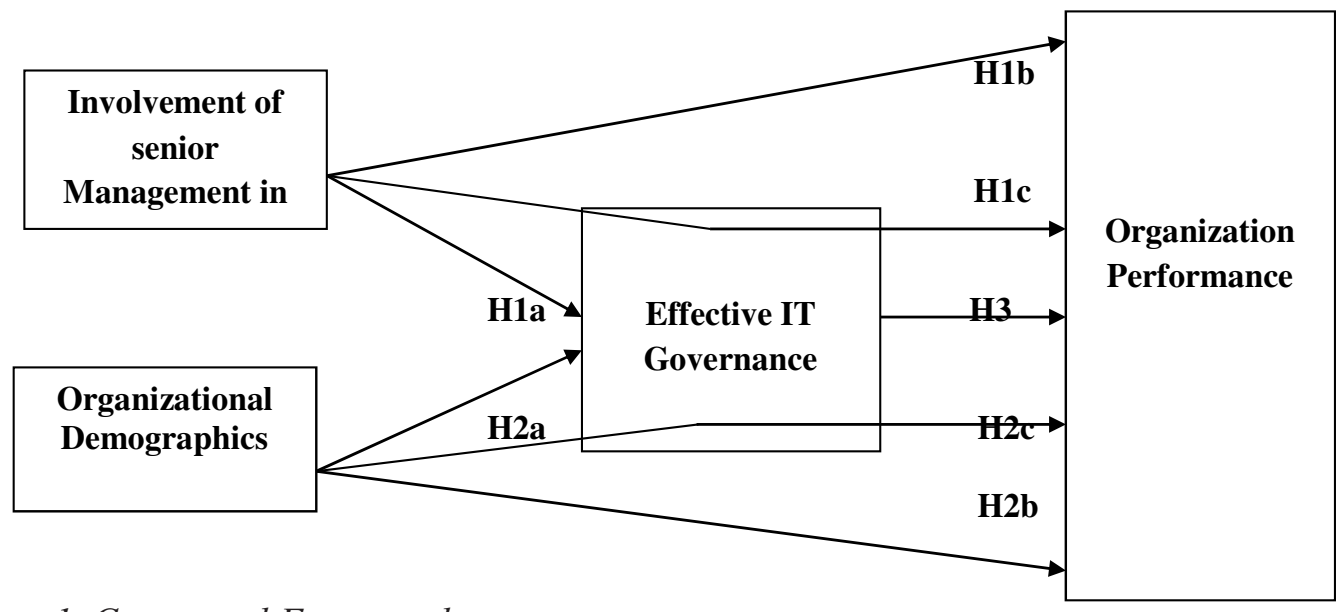

Figure 1. Conceptual Framework 
Selangor (29.7\%), Penang (13.6\%), Johor (12.6\%), Sarawak (10.3\%) Negeri Sembilan (7.0\%) Melaka (4.6\%) and Pahang (4.6\%) (statistic.gov.my, 2014). The subjective measures for constructs; namely involvement of senior management in IT, organizational demographics, effective IT governance, performance of organization, is measured by the five-point scale of interval questionnaire, for this research. Size of the sample obtained from the list's member from the Federation of Malaysian Manufacturer and SME Corp Malaysia. This research has used a simple random sampling and obtains from the member of the list from the Federation of Malaysian Manufacturer (FMM, 2014) and SME Corp Malaysia. Based on Table of Krejcie and Morgan, it could be concluded that 5000 individuals are needed for the sample of this research. To be able to improve both validity and reliability, a questionnaire was designed cautiously. Overall 392 questionnaires have been distributed. Then total 366 questionnaires have been collected from 392 distributed questioners since the missing data were excluded from this research. There were nine not usable data from total 357 questioners. Nine questionnaires also have been excluded from the study due to they were all outlier. Therefore, 357 questionnaires were used in order to carry out the analyses. 233 Out of 357 were returned from SMEs companies, and 124 returned from FMM companies. According to the previous management systems studies in Malaysian manufacturing organizations, the response rate is between $20 \%$ and $30 \%$ (Low et al. 2015). In this research, there are 23 items. Since the present research utilized data gathered at the organizational level, a benchmark of results level around 33 percent was regarded. The statistical types of procedures used to investigate the info for addressing the study questions of the study range between simple descriptive statistics, reliability ensure that you correlation examination to advanced structural equation modeling (SEM). Alternatively, AMOS integrates an easy-touse graphical user interface with a sophisticated processing engine for SEM (Arbuckle 2005). Furthermore, selecting AMOS course was strongly reinforced by its comprehensive make use of evaluating mediating results in the new professional and organizational analyses. The CFA was performed with the 23 level items which were produced from the EFA result Absolute suit indices.

\section{MEASURES AND QUESTIONNAIRE DEVELOPMENT}

In this study, the five-point Likert scale was used as the questionnaires were adopted from previous studies (that used 5-likert scale) to keep the scale is the comparability of the results. The English language has used for questionnaires, which used in most of the business in Malaysian. In measuring Involvement of Senior Management in IT, measuring five items were taken from study by Ali and Green, (2012), Organizational Demographics was measured using six items originally from studies by Elbanna and Child, (2007), Mohamed and Kaur a/p Gian Singh, (2012) and Subriadi et al., (2013). Effective IT Governance was measured using six items taken from Mohamed and Kaur a/p Gian Singh, (2012), and Grant et al., (2007). Organizational Performance was measured using six items originally from researches by Mugwe, (2014), Al-Najjar and Kalaf, (2012), and Etim and Agara, (2011). All of the conducted researches by well- 
known scholars were considered as the best reference for developing this questionnaire.

The reliability of the scale measured was by Cronbach's alpha (Hair et al., 2010). Based on Hair et al. (2010), the acceptable value for Cronbach's alpha is 0.7. The values for Cronbach's alpha coefficient are presented in detail in Table I. The alpha values for the scales measuring the dimensions of IT governance, Effective IT Governance and organizational performance were all greater than 0.7 , indicating that the instrument was reliable. The alpha values of Involvement of Senior Management in IT are 0.794, Organizational Demographics is 0.896, Effective IT Governance is 0.901, and organizational performance is 0.812 . Details of scale items, sources, and related $\alpha$ value is summarized in Table 1.

\section{DATA ANALYSIS AND RESULTS}

The investigation of the data and information about the number of factors were done by an exploratory factor. Therefore, confirmatory factor analysis (CFA) was conducted using Covariancebased structural equation modeling (CBSEM) with the software tools of AMOS 20 where the maximum likelihood estimation approach was applied.SEM test is an appropriate tool for this study; SEM permits both confirmatory and exploratory models forming. In other words, SEM is suitable for testing a theory testing and also developing it (Bollen \& Long, 1993). The CFA was performed with the 23 scale items that were derived from the EFA output Absolute fit indices: chi-square (NC), goodness-of-fit index (GFI), adjusted goodness-of-fit index (AGFI) and the root mean square error of approximation (RMSEA) and (2)
Incremental fit indices: Normed fit index (NFI), comparative fit index (CFI), and the Tucker-Lewis index (TLI).

In the first CFA model (Table 2), it was apparent that model fit indices such as goodness-of-fit index $(\mathrm{GFI})=0.825$, GFI $(\mathrm{AGFI})=0.806$ were poor (acceptable threshold. 0.90), and $(\mathrm{RMR})=0.065$ (threshold $<0.06$ ). Which means selected goodness-of-fit indices for the measurement model were improved a lot when the addition of the covariance path between these items The CFA was finalized with 23 items, resulting in Model 2: also all of the fit indexes had acceptable amounts (Chi square $=557.915, d f=409, P$-value $=0.000$, AGFI $=0.921, \quad$ GFI $=0.915, \quad$ CFI $=0.940$, $\mathrm{NFI}=0.900$, and RMSEA $=0.049$ ). From Table 3, it is obvious that the composite reliability and Cronbach values for all the constructs are well above the conventional threshold value of 0.70 . Based on Hair et al., (2010) the acceptable value for Cronbach's alpha is usually 0.7 ; while the values of AVE are well above 0.40 confirming reliability (Duarte \& Raposo, 2010). The high values of each of the factor loadings confirm the Convergent validity. Figures in Table 3 also show the recommended standard value of AVE of the variables confirming their discriminant validity.

\section{HYPOTHESES TESTING}

To assess the mediating path the bootstrapping option in AMOS was selected. Table 4 shows the result of hypotheses testing.

By discussing results from Table 4, There exists a positive relationship between Involvement of senior management in IT $(\beta=0.314, \quad z=2.962, \quad p=0.006)$ and IT 
Table1. Measurement scales, sources and a values

Scale items
Involvement of Senior Management in IT
Senior management gets involved in strategic matters related to the use of
IT within your organization, outside of the IT steering committee.
In your organization, senior management is aware of IT opportunities and
possibilities for the organization.
IT strategy committee provides strategic direction and alignment of IT and
the business issue in your organization.
In your organization, IT steering committee provides leadership benefits
from IT.
In your organization, IT steering committee provides leadership in
managing IT.

\section{Organizational Demographics}

Elbanna \& Child, (2007);

0.896

Your organization's age has effects on achieving information systems effectiveness.

Organization age is an important factor in determining the decision to adopt new technologies.

The bigger your company become, the greater potential impact could be felt from IT existence.

IT usage in large enterprises will be more effective than the smaller companies because IT will be very helpful in simplifying the operating complexity of bureaucratic organization based on larger firm size.

Companies with a young age showed better performance due to its ability to absorb and utilize new technologies.

IT changes very rapidly and often can only be utilized and adapted properly by young companies.

\section{Effective IT Governance}

The structure of IT governance and the position of the decision-making authority in your organization is an important part to determine the efficacy of IT governance.

In your organization, IT governance structures in the sectors must balance effectiveness and efficiency in service provision.

In your organization, the process of strategic decision-making has a positive impact on the overall level of effective IT governance.

Two-way communication and good participation/collaboration relationship between business and IT people are needed in your organization.

Relational mechanisms of IT decision-making processes have a positive impact on the overall level of effective IT governance in your organization. The structure of IT governance and the position of the decision-making authority in your organization is an important part to determine the efficacy of IT governance.

\section{Organizational Performance}

In your organization, revenue growth increased accordingly in last year. In your organization, market share increased accordingly in last year. In your organization, customer retention increased accordingly in last year. In your organization, customer acquisition increased accordingly in last year.

In your organization, customer satisfaction increased accordingly in last year

In your organization, employee's capabilities increased accordingly in last year.

Mohamed \& Kaur a/p Gian Singh, (2012);

Grant et al.,(2007)
0.901

$$
\text { Singh, (2012); }
$$

Subriadi et al., (2013)
0.794 
Table 2. Goodness-of-fit Indices for the Structural Model

\begin{tabular}{cccccccccccc}
\hline Models & CMIN & DF & p & F & RMR & GFI & AGFI & TLI & CFI & NFI & RMSEA \\
\hline Model 1 & 826.363 & 367 & 0.000 & 2.252 & 0.082 & 0.825 & 0.806 & 0.834 & 0.869 & 0.809 & 0.065 \\
Model 2 & 557.915 & 409 & 0.000 & 1.364 & 0.089 & 0.915 & 0.921 & 0.928 & 0.940 & 0.900 & 0.049 \\
\hline
\end{tabular}

mediation test where on the Organization Performance and Effective IT Governance $(\beta=0.247, \quad z=3.127, \quad p=0.019)$ is a full mediator of the effect of Involvement of senior Management in IT.

As Table 4 shows, Organizational Demographics $(\beta=503, z=3.619, p=0.000)$ and Effective IT Governance have a significant relationship, therefore supporting hypothesis H2a. Similarly, Organizational Demographics $(\beta=0.202, z=1.530, p=0.127)$ had no significant influence on Organization Performance, no supporting hypothesis $\mathrm{H} 2 \mathrm{~b}$. Finally, Effective IT Governance $(\beta=0.386$, $z=3.386, p=0.063$ ) was found to have the full mediating effect on the association between Organizational Demographics and Organization Performance, supporting hypothesis $\mathrm{H} 2 \mathrm{c}$.

The study results in this research show that Effective IT Governance $(\beta=0.397$, $z=2.738, p=0.000)$ is found to have a significant and positive relationship with Organization Performance that supports hypothesis H3. Figure 2 shows the Structural model of this study.

\section{DISCUSSIONS OF FINDINGS}

Research by Ali and Green (2012) reveals that the involvement of senior management affects the level of an effective ITG in a positively significant manner. Overall, the support from the management is an essential component of adopting and implementing IT outsourcing for firms. The support of the senior management has an effect on the success of initiatives on new systems through the promotion of employee empowerment, through the facilitation of employee engagement, through the promotion of a culture shift and enhanced commitment by the employees of an organization, through the act of giving rewards and incentives that influence employees' behaviors, through the offer of training and the improvement of communications across departments and motivating teamwork in the organizations. The study by Young and Jordan (2008) confirms the core support from the top management is linked to successful decision making to control the IT outsourcing strategies and authorize the changes in the business process. A critical component of an

Table 3. Reliability and validity measures

\begin{tabular}{lccccccc}
\hline \multicolumn{1}{c}{ Constructs } & $\begin{array}{c}\text { Composite } \\
\text { Reliabiliy }\end{array}$ & AVEa & $\begin{array}{c}\text { Cronbach's } \\
\boldsymbol{\alpha}\end{array}$ & $\begin{array}{c}\text { Involvement } \\
\text { of senior } \\
\text { management } \\
\text { in IT }\end{array}$ & $\begin{array}{c}\text { Organizational } \\
\text { Demographic }\end{array}$ & $\begin{array}{c}\text { Effective } \\
\text { IT } \\
\text { governance }\end{array}$ & $\begin{array}{c}\text { Organizational } \\
\text { performance }\end{array}$ \\
\hline $\begin{array}{l}\text { Involvement of } \\
\text { senior management } \\
\text { in IT }\end{array}$ & 0.834 & 0.42 & 0.794 & 0.42 & & \\
$\begin{array}{l}\text { Organizational } \\
\text { Demographics }\end{array}$ & 0.889 & 0.53 & 0.896 & 0.039 & 0.53 & \\
$\begin{array}{l}\text { Effective IT } \\
\text { governance }\end{array}$ & 0.878 & 0.52 & 0.901 & 0.040 & 0.063 & 0.52 & 0.49 \\
$\begin{array}{l}\text { Organizational } \\
\text { performance }\end{array}$ & 0.907 & 0.49 & 0.812 & 0.028 & 0.033 & 0.032 & \\
\hline
\end{tabular}


Table 4. AMOS output for hypotheses testing

\begin{tabular}{|c|c|c|c|c|c|}
\hline Hypotheses & Paths & SE & $\begin{array}{l}\text { AMOS } \\
\text { output } \\
\text { CR (t) }\end{array}$ & P-Value & Results \\
\hline $\begin{array}{l}\text { H1a. There is a significant relationship } \\
\text { between Involvement of senior Management } \\
\text { in IT and Effective IT Governance. }\end{array}$ & $\mathrm{I} \rightarrow \mathrm{G}$ & 0.314 & 2.962 & $0.006^{* *}$ & Supported \\
\hline $\begin{array}{l}\text { H1b. There is a significant relationship } \\
\text { between Involvement of senior Management } \\
\text { in IT and Organization Performance. }\end{array}$ & $\mathrm{I} \rightarrow \mathrm{P}$ & 0.123 & 1.337 & 0.178 & $\begin{array}{c}\text { Not } \\
\text { Supported }\end{array}$ \\
\hline $\begin{array}{l}\text { H1c. Effective IT Governance mediates the } \\
\text { relationship between Involvement of senior } \\
\text { Management and Organization } \\
\text { Performance. }\end{array}$ & $\mathrm{I} \rightarrow \mathrm{G} \rightarrow \mathrm{P}$ & 0.079 & 3.127 & $0.019^{*}$ & Supported \\
\hline $\begin{array}{l}\text { H2a. There is a relationship between } \\
\text { Organizational Demographics and Effective } \\
\text { IT Governance. }\end{array}$ & $\mathrm{I} \rightarrow \mathrm{G} \rightarrow \mathrm{P}$ & 0.079 & 3.127 & $0.019^{*}$ & Supported \\
\hline $\begin{array}{l}\text { H2a. There is a relationship between } \\
\text { Organizational Demographics and Effective } \\
\text { IT Governance. }\end{array}$ & $\mathrm{D} \rightarrow \mathrm{G}$ & 0.281 & 1.653 & 0.233 & $\begin{array}{c}\text { Not } \\
\text { Supported }\end{array}$ \\
\hline $\begin{array}{l}\text { H2b. There is a relationship between } \\
\text { Organizational Demographics and } \\
\text { Organization Performance. }\end{array}$ & $\mathrm{D} \rightarrow \mathrm{P}$ & 0.503 & 3.619 & 0.000 & Supported \\
\hline 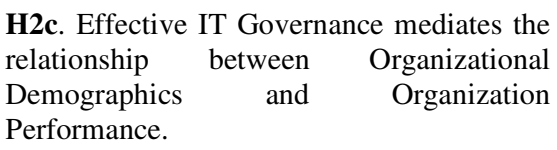 & $\mathrm{D} \rightarrow \mathrm{G} \rightarrow \mathrm{P}$ & 0.386 & 3.386 & 0.063 & Supported \\
\hline $\begin{array}{l}\text { H3. There is a relationship between } \\
\text { Effective IT Governance and Organization } \\
\text { Performance. }\end{array}$ & $\mathrm{G} \rightarrow \mathrm{P}$ & 0.397 & 2.738 & $0.000 * * *$ & Supported \\
\hline
\end{tabular}

effective proposal for support from top management is linked to enhanced decision making to manage strategies. The top management has to respond and manage business strategies and processes. Effective mitigation is dependent on the commitment and support from the top level management. This study supports the significant relationships between involvement of senior management and effective IT governance In Malaysian manufacturing companies. Although studies have validated the positive effect of involvement of senior management on organization performance (Bowen et al., 2007; Bouwes, 2013), the correlation between senior management support and organizational activity success has also been thoroughly researched (Bowen et al., 2007). Senior management involvement can arise naturally or by explicit appointment of a project champion picked from the senior management. The positive effect of senior management involvement on effective IS planning has been identified by (Bouwes, 2013). The correlation between senior management support and organizational activity success has also been thoroughly researched (Bowen et al., 2007) senior management involvement has a significant positive relation with IT governance success. Bouwes, 2013 Recognized senior management involvement the most important enabler of business and IT alignment. In this research, the result showed that there is no significant relationship between involvement of senior management and organization performance in Malaysian manufacturing companies. Hence, this 
research this study supported the mediating effect of effective IT governance between involvement of senior management and organization performance in Malaysian manufacturing companies.

Previous research on organizational demographics and effective IT governance studies (Lee et al., 2012; Mohamed \& Kaur $\mathrm{a} / \mathrm{p}$ Gian Singh, 2012) examined organizational demographics on effective IT governance; Past research shows an inverse relationship between firm size and structure with bigger firms being decentralized (Mohamed \& Kaur a/p Gian Singh, 2012). Bernroider (2008) claimed that bigger firms observe improvement in the success of ERP systems when the top management commitment to ITG increases. The firm's age reflects the duration that a firm has been established. In a quantitative study in the US, (Lee et al., 2012) discovered that firm's age is negatively related to firm performance. In an earlier study, it was found that CEOs are more likely to practice formalization and implement centralized structures in younger Canadian firms. Firm age produces mixed results in the adoption of IT. According to Mohamed \& Kaur a/p Gian Singh, 2012), firm age is a critical factor in deciding on adopting new technologies. Therefore this study supports the significant relationships between organizational demographics and effective IT governance in Malaysian manufacturing companies. According to Mohamed \& Kaur a/p Gian Singh, 2012), firm age is a critical factor in deciding on

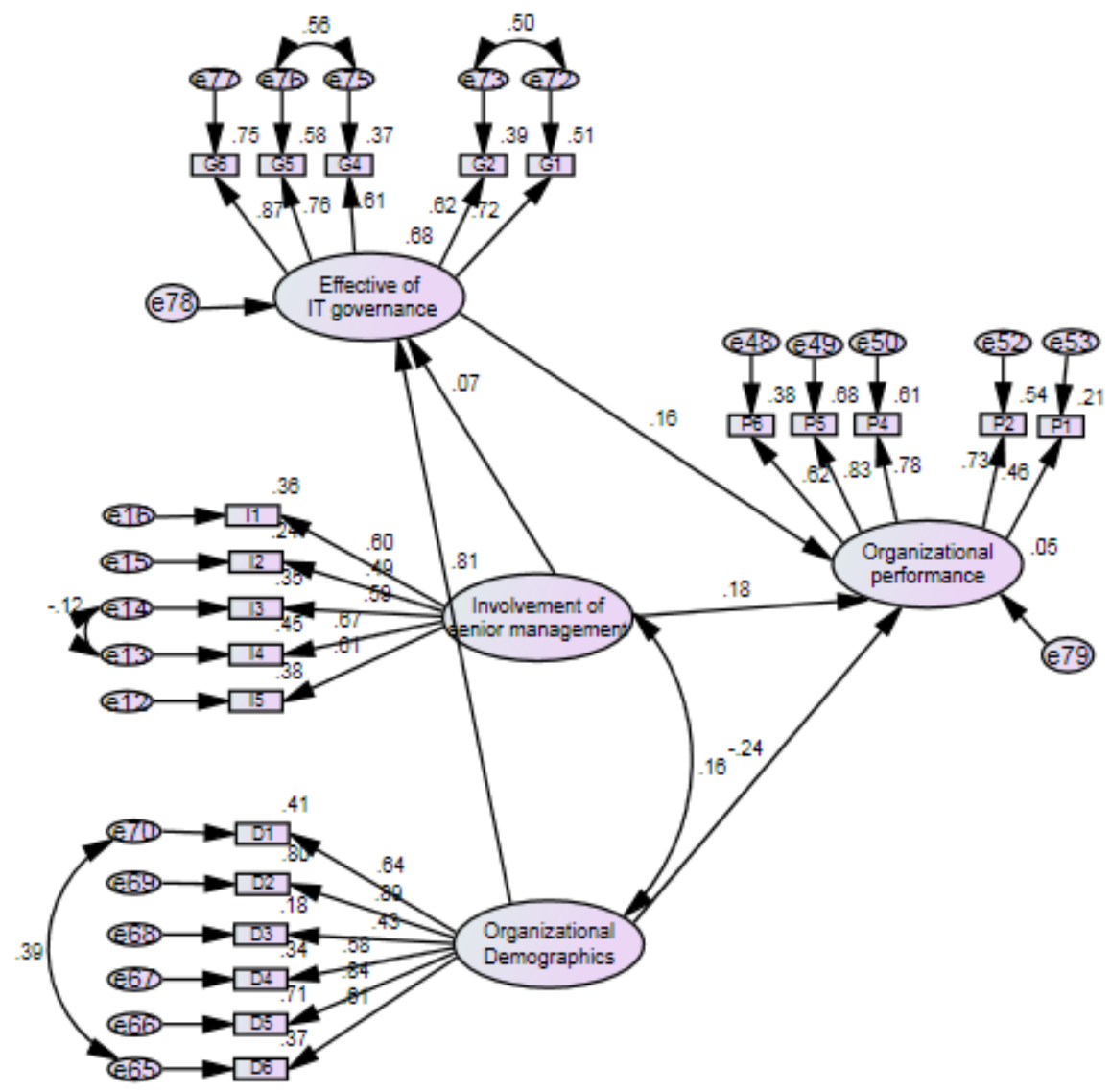

Figure 2. Structural model of this study 
adopting new technologies. Large firms are more likely to make large profits. New firms with less formalized structures may be better at capitalizing the benefits of gender diversity such as creativity and innovation compared to old firms. Firm age was operationalized using the number of years since the organization was established. Many organizations at present find it challenging because IT is changing rapidly and these changes can only be used and properly adapted by the younger organizations (Subriadi et al., 2013). In this study, the result showed that there is no significant relationship between organizational demographics and organization performance in Malaysian manufacturing companies. Hence, this study supported significant the mediating effect of effective IT governance between organizational demographics and organization performance in Malaysian manufacturing companies.

ITG is a critical capability of a firm in promoting the alignment of its IT and business strategy as well as the IT delivery of value to the business. In order to establish the ITG, a firm can use the practices linked to structures of decision making, and related tools; nevertheless, the particular benefit of the various practices have been poorly identified (De Souza Bermejo et al., 2014). Most extant researches have attempted to calculate the performance of IT using the measurement of the quantity of the returns of the decisions made on IT investment; using common forms of financial measurements such as the ROI, NPV (net present value, and others at the firm level. Certain scholars have utilized the performance of the organization seen as the result of the performance of IT that represents an increase in the market share, the attained competitive edge, enhanced internal efficacy in the operations of the firm, as well as the growth of the sales revenue annually (Heindrickson. \& Santos, 2014). According to Haanappel (2011), financial performance may not be a proper measurement approach in the analysis of the performance of IT; it was proposed to utilize the perceived advantages derived from the performance of the organization such as the product delivery, operations, customer service, and human resource. According to Pick, (2015), the performance of IT is marked by outstanding and effective processes and structures for ITG. Li et al. (2014) discovered a strong and positive relation between the implementation of ITG and organizational performance; however, they did not uncover any direct effect on ITG on the performance of IT investment in Canada and the USA. Li et al. (2014) propose that the efficacy of ITG affects ITG and the success of IT implementation. Hence this research result has added confirmation that effective IT governance has a significant effect on organization performance in the Manufacturing companies in Malaysia.

\section{CONCLUSIONS}

As a result, this study has focused on senior management's involvement and demographics of organizational, effective IT governance and performance of organization in Malaysian manufacturing companies. Considering the importance of information technology management in Malaysia, this research can help Managers and researchers to promote their knowledge about the importance of ITG and how it can benefit organization performance. According to the literature, by considering both IT governance initiatives factors such as (senior management's involvement and 
demographics of organizational) and scarce as the study had been executed, data effective ITG and their impact on collection and evaluation in this research manufacturing companies, effective ITG could reap the benefits of additional assets to could enhance organization performance. In assemble data from extra case sites from fact, the findings provided useful very similar small and moderate companies information related to ITG that enlightened in various other geographic areas.

companies to their Productivity and performance, and assists them to survive in the hypercompetitive world.

\subsection{Limitation}

The findings and results of this research were valid and valuable due to the supportive wide range of literature and theoretical viewpoint. However, as in the majority of survey research, there are some limitations, which are unavoidable; there is two limitations for this research as explained below:

Firstly, today's research was constrained simply by the actual fact that data collected and analyzed originated from IT managers; the outcomes may well not become generalized to the bigger cross culture inhabitants. The effect of IT Governance Initiatives and effective IT governance varies between agencies in Eastern countries and Western countries or between agencies in created countries and developing countries. The data of the generalizability of results abroad provides the practitioners and academicians a more powerful basis in applying the proposed model with their business or study application.

Secondly, the analysis could reap the benefits of additional cases to enhance the generalizability of the research's results. This research had not been sponsored by an internal or external financing entity and the cover research actions was limited by the income of the researcher. Field analysis is costly and time-eating. As both assets were

\subsection{Future Research}

Nevertheless, in response to the over limitations, listed below are discovered as areas for future research.

As the data achieved through a crosssectional approach could moderate the conclusion's strength, a longitudinal approach might be more beneficial in investigating the causal links between the observed variables in this study. A panel study could be used for longitudinal study design to examine a similar set of the sample over a longer period of time. Researchers would be able to identify response continuity and patterns and trends by examining a similar sample population over a longer period of time. This research ought to be extended due to the accessible and different sample size. Additional analysis in replicating this research can be carried out an industry-specific setting, such as service. As a result, in this research the majority of manufacturing industry in Malaysia are using IT Governance in their business that can help in organizational performance. In pursuit of a far more generalized study, an upcoming analysis is encouraged to research this model in various other sectors and developing countries.

\section{References}

Ali, S., \& Green, P. (2012). Effective information technology (IT) governance 


\title{
КРИТИЧНИ ФАКТОРИ ИТ УПРАВЉАНА И ЊЕГОВОГ УТИЦАЈА НА ОРГАНИЗАЦИОНЕ ПЕРФОРМАНСЕ У МАЛАЗИЈСКОЈ ПРОИЗВОДНОЈ ИНДУСТРИЈИ
}

\author{
Bentolhoda Abdollahbeigi, Farhang Salehi
}

\section{Извод}

Сврха ове студије је испитивање у којој мери учешће вишег руководстава и демографија организације утичу на ефикасност управљања ИТ-ом у односу на перформансе организација. Ово је комбинација експлораторног и дескриптивног истраживања које има за циљ да истражи детерминанте ИТ управљања и његове ефекте на организационе перформансе у малезијским производним компанијама. Узорак величине 357 испитаника је прикупљен за ово истраживање. Коришћено је Моделирање структурних једначина (енг. Structural equation modeling - SEM) како би се истовремено испитали мерни и структурни модел. Добијени резултати су показали везе између укључености вишег руководства и организационе демографије и њиховог ефикасног управљања и организационих перформанси у производним компанијама у Малезији. Ово истраживање представља конструисање теоретски заснованог модела, који асимилира укљученост вишег руководства и организациону демографију, ефикасно управљање информатичким технологијама и перформансе организација. Такође, открива најважније елементе који утичу на ефикасно управљање ИТ-ом како би се побољшале перформансе производне компаније.

Кључне речи: ИТ управљање у Малезији, учешће вишег менаџмента у ИТ-у, организациона демографија, ефикасно управљање ИТ-ем, перформансе организације

mechanisms: An IT outsourcing perspective. Information Systems Frontiers, 14 (2), 179193.

Al-Najjar, S.M., \& Kalaf K.H. (2012). Designing a balanced scorecard to measure a bank's Performance, A Case Study. International Journal of Business Administration, 3 (4), 44-53.

Bernroider, E.W.N. (2008), “IT governance for enterprise resource planning supported by the DeLone-McLean model of information systems success", Information \& Management, Vol. 45 No. 5, pp. 257-269.

Bouwes, R., (2013). IT governance effect size: Evaluating the impact of Senior Management involvement on different organizational strategies. University of Amsterdam, Amsterdam, Netherlands.
Retrieved

from https://scripties.uba.uva.nl/download?fid=54 3333

Bowen, Frances E., Mahdi Rostami, \& Piers Steel (2010). Timing is everything: A meta-analysis of the relationships between organizational performance and innovation, Journal of Business Research, 63(11), 117985.

Callahan, J., \& Keyes, D. (2004). The evolution of IT Governance @ NB Power. In Grembergen (Ed.), Strategies for Information Technology Governance: Idea Group Publishing.

Castro, H.G.D., \& Carvalho, M.M.D. (2012). Gerenciamento do portfolio de projetos: um estudo exploratório. Gestão \& Produção, São Carlos, v. 17, n. 2, p. 283-296, 
2010 . Available

$<$ http://www.scielo.br/pdf/gp/v17n2/a06v17 n2.pdf $>$.

De Haes, S., Van Grembergen, W., \& Debreceny, R.S. (2013). COBIT 5 and Enterprise Governance of Information Technology. Building Blocks and Research Opportunities, Journal of Information Systems, 27 (1), 307-324.

De Souza Bermejo, P.H., Tonelli, A.O., Zambalde, A.L., dos Santos, P.A., \& Zuppo, L. (2014). Evaluating IT governance practices and business and IT outcomes: A quantitative exploratory study in Brazilian companies. Procedia Technology 16, 849 857.

Duarte, P.A., \& Raposo, M.L. (2010). A PLS model to study brand preference: an application to the mobile phone market. In: Esposito Vinzi, V., Chin, W.W., Henseler, J., Wang, H. (eds) Handbook of partial least squares: concepts, methods, and applications. Springer, Heidelberg, 449-485.

Elbanna, S., \& Child, J. (2007). Influences on strategic decision effectiveness: Development and test of an integrative model. Strategic Management Journal, 28 (4), 431-453.

Etim, R.S., \& Agara, I.G. (2011). The balanced scorecard: The new performance management paradigm for Nigerian firms. Journal of Economic Development Research and Investment 2 (3), 64-73.

Gartner (2010) Gartner Perspective: IT Spending 2010. Retrieved from https://www.gartner.com/en/informationtechnology.

Grant, G., Brown, A., Uruthirapathy, A., \& McKnight, S. (2007). An Extended Model of IT Governance: A Conceptual Proposal. AMCIS Proceedings. 215.

Guilherme L. L., Antonio C.G.M., and João L.B. (2014). IT Governance
Effectiveness and its Antecedents: an Empirical Examination in Brazilian Firms.47th Hawaii International Conference on System Science.

Haanappel, S., (2011). A framework for IT performance management. , (February), pp.1-83.

Hair, J.F., Black, W.C., Babin, B.J., \& Anderson, R.E. (2010). Multivariate data analysis (7th ed.). Upper Saddle River, New Jersey: Pearson Education International.

Heindrickson, G., \& Santos Jr, C.D. (2014). Information Technology Governance in Public Organizations: How Perceived Effectiveness Relates To Three Classical Mechanisms. Journal of Information Systems and Technology Management, 11 (2), 297-326.

Héroux, S., \& Fortin, A. (2014). Exploring IT Dependence and IT Governance. Information Systems Management, 31 (2), 143-166.

Héroux, S., \& Fortin, A. (2017). Exploring the Influence of Executive Management Diversity on it Governance. Journal of Information Systems and Technology Management, 14 (3), 401-429.

Huygh, T., Haes, S.D., Joshi, A., \& Grembergen, W.V. (2018). Answering Key Global IT Management Concerns Through IT Governance and Management Processes: A COBIT 5 Proceedings of the 51st Hawaii International Conference on System Sciences , 5335-5344.

Iden, J., \& Eikebrokk, T.R., (2015). The impact of senior management involvement, organizational commitment and group efficacy on ITIL implementation benefits. Information Systems and e-Business Management. 13 (3), 527-552.

ISACA, (2012). A Business Framework for the Governance and Management of Enterprise IT. Rolling Meadows, IL (USA): 
ISACA, 2012. Available at: $<$ http://www.isaca.org/COBIT/Pages/default .aspx $>$.

Kairu, E.W., Wafula, M.O., Okaka, O., Odera, O., \& Akerele, E.K. (2013). Effects of balanced scorecard on a performance of firms in the service sector. European journal of business and management, 5 (9), 81-88.

Lee, O.K. et al., (2012). It impacts on performance of service firms through operation-level dynamic capability. Journal of Applied Business Research, 28(6), pp.1283-1294.

Li, L., Gao, P. \& Mao, J., (2014). Research on IT in China: a call for greater contextualization. Journal of Information Technology, 29(3), pp.208-222.

Loderer, C., \& Waelchli. U. (2010). Protecting Minority Shareholders: Listed versus Unlisted Firms. Financial Management, 39 (1), 33-57.

Low, V.L., Tay, S.T., Kho, K.L. (2015). Molecular characterisation of the tick Rhipicephalus microplus in Malaysia: new insights into the cryptic diversity and distinct genetic assemblages throughout the world. Parasites Vectors 8, 341.

Marnewick, C., \& Labuschagne, L. (2011). An investigation into the governance of information technology projects in South Africa. International Journal of Project Management, 29 (6), 661-670.

Mohamed, N., \& Kaur a/p Gian Singh, J. (2012). A Conceptual Framework for Information Technology Governance Effectiveness in Private Organizations. Information Management \& Computer Security, 20 (2), 88-106.

Mugwe, C.W. (2014). Determinants for Effective Information Technology Outsourcing: A Case of International Business Machines Corporation Kenya (Master thesis). University Of Nairobi.
Retrieved

from

http://erepository.uonbi.ac.ke/handle/11295/ 73584

Nfuka, E. N., \& Rusu, L. (2011). The effect of critical success factors on IT governance performance. Industrial Management \& Data Systems, 111(9), 14181448.

Othman, M.F.I. (2016). Barriers to the adoption of formal IT governance practice: A Malaysian case ( $\mathrm{PhD}$ thesis), Queensland University of Technology. Brisbane, Queensland, Australia.

Pick, R.A., (2015). Centralization And Decentralization In Information Technology Governance Shepherd Or Servant: , 19(2), pp.61-68.

Rubino, M., \& Vitolla, F. (2014). Corporate governance and the information system: how a framework for IT governance support ERM. Corporate Governance, 14 (3), 320-338.

Subriadi, A.P., Hadiwidjojo, D., Djumahir, Rahayu, M., \& Sarno., R. (2013), Firm Age, Firm Size and Information Technology Intensity Industry Factors in Influencing Information Technology Contribution to Improve Performance, Journal of Theoretical and Applied Information Technology, 54 (3), 487-496.

Tan, K.S., Teo, W.L., \& Lai, K.P. (2011), The applicability of information technology governance in the Malaysian SMEs, Journal of Innovation Management in Small and Medium Enterprises, 2011, 1-10.

Teo, W.L., Manaf, A.A., \& Choong, P.L.F., (2013). Perceived effectiveness of information technology governance initiatives among IT practitioners. International Journal of Engineering Business Management, 5 (19), 1-9.

Vaswani, R. (2003). Determinants of Effective Information Technology (IT) 
Governance. Unpublished Thesis. School of Business, University of Queensland, Australia.

Veerankutty, F., \& Ali, N.A., (2016). Information Technology Governance on Public Sector Audit Performance.nternational Proceedings of the Conference on Accounting Studies (ICAS) 2016, 15-18August 2016, 41-48. Langkawi, Kedah, Malaysia.

Weill, P., \& Ross, J. W. (2004). IT governance: How top performers manage IT decision rights for superior results. Boston, MA: Harvard Business School Press.

Young, R., \& Jordan, E.,( 2008). Top management support: mantra or necessity? International Journal of Project Management 26, 713-725. 